\title{
FIRST RECORD OF THREE SPECIES OF PYTHIUM FROM MOROCCAN WATERS
}

\author{
Amal EL ANDROUSSE ${ }^{1}$, Aicha EL AISSAMI ${ }^{1 *}$, Mohamed RAHOUTI ${ }^{1}$, Houria \\ LAHLOU $^{1}$, Samira BEN ABDELLAH ${ }^{2}$ \& Françoise SEIGLE MURANDI ${ }^{3}$ \\ ${ }^{1}$ Laboratoire de Botanique, Département de Biologie, Université Med V, Rabat, Maroc. \\ ${ }^{2}$ Laboratoire Central de 1'Office National de l'Eau Potable, Rabat, Maroc; \\ ${ }^{3}$ Laboratoire de Botanique et Cryptogamie, Université Joseph Fourier, Grenoble, France. \\ *Corresponding author: elaisami@fsr.ac.ma
}

Recibido el 12 de febrero de 2006, aceptado para su publicación el 31 de diciembre 2006 Publicado "on line" en febrero de 2007

\begin{abstract}
First record of three species of Pythium from Moroccan waters. Species of Pythium, including P.torulosum, P.catenulatum and P. "Group F", isolated from dam near Rabat city (capital of Morocco) in northern Africa, are described. Taxonomic and morphological details of the fungi are discussed. This work is the first report of these species from Moroccan waters.
\end{abstract}

Keywords. Antheridia, biodiversity, Morocco, oogonia, Pythium, sporangia.

RESUMEN. Primeras citas de tres especies de Pythium para Marruecos. Se describen especies de Pythium, incluyendo P. torulosum, P. catenulatum y P. "Group F", aislados cerca de la ciudad de Rabat (Marruecos) en el norte de Africa. Se discuten detalles taxonómicos y morfológicos del hongo. Este trabajo es la primera refencia de estas especies en aguas de Marruecos.

Palabras clave. Anteridios, biodiversidad, Marruecos, oogonios, Pythium, esporangios.

\section{INTRODUCTION}

Morocco, a country characterized by semi-arid conditions, the resort to surface water supply demands is always a challenge, given the scarceness of water and the limit of economical and social development. Currentely $62 \%$ of potable water production is assured from dam reservoirs (ONEP, 1998). These latter are often affected by the eutrophication phenomenon which lead to the excessive growth of microorganisms. Aquatic pythiaceous fungi, particularly species within the genus Pythium, together with other aquatic microorganisms constitute the fungal flora of fresh water (PlaatsNiterink, 1981).

Pythium species are widely distributed in the world. They are the major pathogens associated with damping-off of seeds and seedlings (Garret, 1970; Hendrix and Campbell, 1973; Raynal, 1980; Walker et al., 
1998; Kageyama and Nelson, 2003). Within this context a study to isole and identify some aquatic pythiaceous fungi from Moroccan waters has been undertaken at the University in Rabat.

A number of water samples taken from dam were examined. This dam situated in the Bassin of Bourgreg has a surface of $28 \mathrm{~km}^{2}$ and a total capacity of 493 million $\mathrm{m}^{3}$. It makes it possible to supply drinking and industrial water to the centers and cities located in the bassin of Bourgreg and the cities between Kénitra and Casablanca (ONEP, 1996).

In this report three species of Pythium are reported. These species have been described in others countries (PlaatsNiterink, 1981; Paul, 1982, 1994 a) but not from Morocco's waters. This paper is the first record of its occurrence from Moroccan waters.

\section{MATERIALS AND METHODS}

Water samples were collected from different places of the dam reservoir. These were baited with boiled hemp-seed halves (Paul, 1986 a-c). The colonised baits were washed thoroughly with sterilised distilled water. With a fine pointed forceps one hypha was removed, placed on the surface of potato carrot agar (PCA) and incubated in the dark at room temperature. A small block of agar with hyphal tips was cut from the edge of the colony and transferred to a fresh plate of PCA.

To study asexual and sexual reproduction, small piece of agar block having bacteria-free mycelium was placed in a petri dish in shallow layer of sterile distilled water, to which several boiled hemp-seed halves and 1-2 cm of boiled grass leaf were added (Plaats-Niterink, 1981). In 3-4 days the baits were colonized by the fungus. Changing the water additionally favours the production of sporangia and discharge of zoospores (Plaats-Niterink, 1981). Temperature/growth relations were observed on potato carrot agar. Identification of the fungi was done with the help of keys and descriptions of Middleton (1943), Waterhouse (1967), Plaats-Niterink (1981) and Dick (1990).

\section{RESULTS}

Pythium torulosum Coker \& Patterson (Figures 1-9)

Mycelium hyaline, well branched. Main hyphae up to $5 \mu \mathrm{m}$ wide. Colonies on PCA are submerged showing a rosette pattern. On this medium the average daily growth of the fungus at $25^{\circ} \mathrm{C}$ is $14.5 \mathrm{~mm}$. Sporangia consisting of filamentous inflated, branched outgrowths of the mycelium, forming toruloid elements of various sizes. Vesicles and zoospores are formed plentifully in water cultures at room temperature $\left(18-24^{\circ} \mathrm{C}\right)$. Encysted zoospores measure between 6.5$9 \mu \mathrm{m}$ in diameter (av. $7.5 \mu \mathrm{m}$ ). Oogonia smooth walled, terminal but at times intercalary, $12-20 \mu \mathrm{m}$ (av. $17 \mu \mathrm{m}$ ) in diameter. Antheridia 1-2 per oogonium, monoclinuous, antheridial cells clavate making apical contact with the oogonium. Oospores plerotic, single, $10-19 \mu \mathrm{m}$ in diameter (av. $15 \mu \mathrm{m})$. Wall 1-2 $\mu \mathrm{m}$ in thickeness.

\section{Pythium catenulatum Matthews}

(Figures 10-21)

Mycelium hyaline, well branched. Main hyphae up to $5 \mu \mathrm{m}$ wide. Colonies on PCA submerged, giving a narrow chrysanthemum pattern. Daily growth rate on this medium at $25^{\circ} \mathrm{C}$ is $12 \mathrm{~mm}$. Sporangia composed of globose, ellipsoidal to irregular swollen elements, connected with branched parts of the mycelium. Vesicles and zoospores formed at 


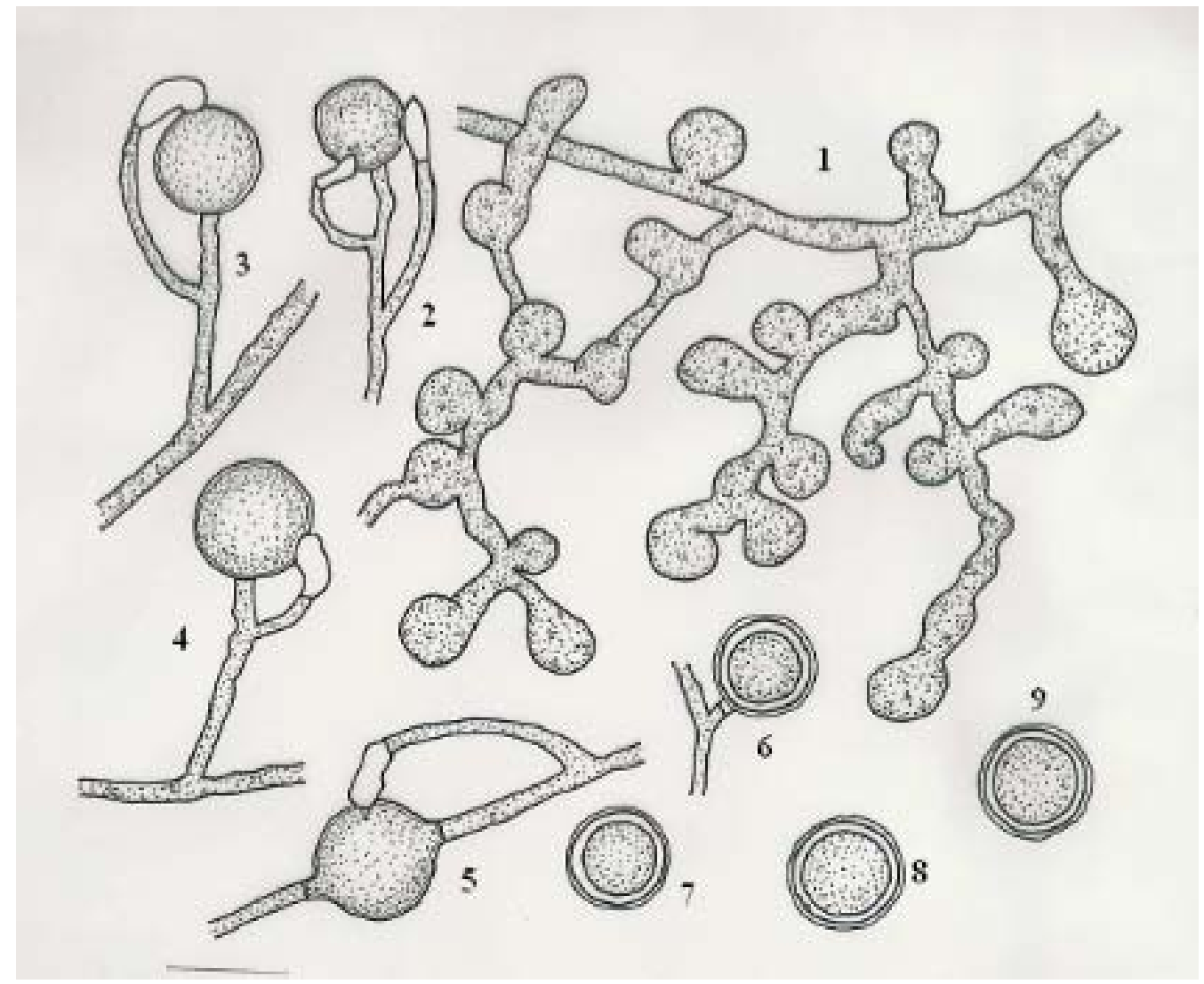

Figures 1-9: Pythium torulosum. 1: Filamentous inflated sporangia. 2: Terminal oogonia and monoclinuous antheridia (two per oogonium). 3 and 4: Terminal oogonia and monoclinuous antheridia (one per oogonium). 5: Intercalary oogonia and monoclinuous antheridia. 6-9: Plerotic oospores. $(\mathrm{Bar}=20 \mu \mathrm{m})$.

room temperature. Encysted zoospores measures about 8-9 $\mu \mathrm{m}$ in diameter. Hyphal swellings abundant, of various shapes and sizes, mostly spherical but at times ellipsoidal or oval shaped. The spherical ones measure 10 to $23 \mu \mathrm{m}$ in diameter (av. $17 \mu \mathrm{m}$ ). They can either be terminal or intercalary, mostly in chains of 3-8. Oogonia terminal or intercalary, smooth-walled, 13-29 (av. 22 $\mu \mathrm{m}$ ). Antheridia diclinuous, occasionally monoclinuous, 2-8 per oogonium. Oospores plerotic, single, 12-27 $\mu \mathrm{m}$ in diameter (av. $20 \mu \mathrm{m}$ ) with a wall of about $1.5 \mu \mathrm{m}$ thick.

\section{Pythium "Group F"}

(Figures 22-24)

Mycelium hyaline, well branched. Main hyphae up to $4.5 \mu \mathrm{m}$. Daily growth rate on PCA at $25^{\circ} \mathrm{C}$ is $8.5 \mathrm{~mm}$. On this medium the colonies forme little loose aerial mycelium with a rizoidal pattern, and a heap of mycelium like points in some places. Microscopically an aggregate of chlamydospores were observed. These latter are in various shapes, spherical, ellipsoidal or totally irregular. Sporangia were of filamentous non-inflated type, which 


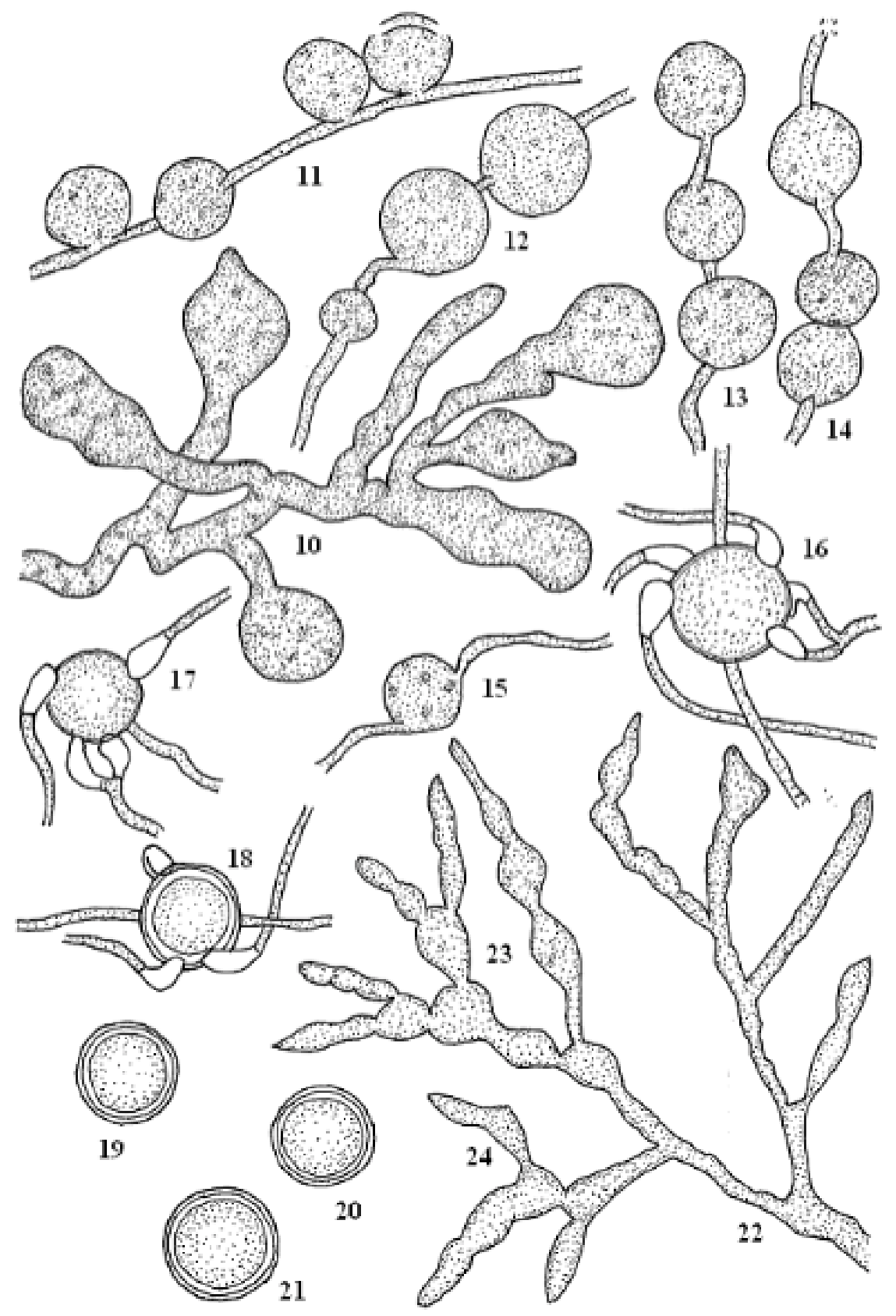

Figures 10-21: Pythium catenulatum. 10: Irregularly swollen sporangia. 11-14: Catenulate hyphal swellings. 15: Spherical hyphal swelling. 16-18: Oogonia with diclinuous antheridia. 19 and 21: Plerotic oospores. $($ Bar $=20 \mu \mathrm{m})$. 22-24: Pythium “Group F”. 22: Hyphae. 23-24: Chlamydospores. $($ Bar $=25 \mu \mathrm{m})$. 
produce vesicles at the top of long evacuation tubes. Zoospores were formed at room temperature $\left(18-24^{\circ} \mathrm{C}\right)$. Sexual reproduction absent.

\section{DISCUSSION}

Pythium species are spread all over the world. They have been reported in ponds, lakes, rivers (Paul, 1982, 1986, 1994a), canals (Abdelzaher et al., 1997), dam reservoirs (Paul, 1986b, 1986c) and soils (Paul, 1994a, 1994b, 2002). Many Pythium species are well known to affect a wide range of plants, mainly juvenile or succulent tissues and causing considerable economical losses to a wide of agricultural crops (Hendrix and Campbell, 1973; Cline et als., 1988).

Pythium torulosum is a common pythiaceous fungi. It has been isolated from barley, grasses, maize, conifers, soils and waters (Plaats-Niterink, 1981). In Africa this species has been described from Algeria (Paul, 1982) and from the republic of Benin (Paul, 1994a). However, our study is the first report in Morocco. Most of the morphological features of this isolate are in common to those described elsewhere.

Pythium catenulatum was originally isolated in the USA from plant debris in water, and later also from soil and turf grasses (Plaats-Niterink, 1981). The species is quite rare, and in the north of Africa, it has been recorded only from Algeria (Paul, 1982). This is the first report of its presence in Morocco. A part from its slow growth, 12 $\mathrm{mm}$ /day instead of $14 \mathrm{~mm} /$ day recorded by Plaats-Niterink (1981), most of the morphological characters fit closely the description of the species found in the literature.

Pythium "Group $F$ ", a typical aquatic fungus, has been isolated from different
Algerian waters (Paul, 1982) and also from canal water in Egypt (Abdelzaher et al., 1997). This species belongs to isolates which did not produce any oogonia in single or dual cultures. The morphological description of the Moroccan isolate treated in this paper resembles in almost all the characters of Pythium "Group F" reported in Algeria (Paul, 1982). This is also the first taxonomic treatment of the species in Morocco.

Only a very limited area was studied during this work and it is expected that the inclusion of other regions in Morocco in future investigations will increase the list of the striminipilan Pythium species.

ACKNOWLEDGMENTS. We thank Pr. B. Paul of the Institute Jules Guyot (Université de Bourgogne Dijon France) for his help in the identification of fungi. This work was supported by Franco-Moroccan cooperation (MA/02/51) and Moroccan program of scientific research (P.R.O.T.A.R.S)

\section{REFERENCES}

ABDELZAHER, H.M.A., M.A. ELNAGHY, E.M. FADL-ALLAH \& S.S. ZOHRI -1997 Some physical and chemical factors affecting asexual reproduction of three Pythium spp. Cryptogamie Mycologie 18 (3): 267-277.

Cline, M.N., G.A. CHASTAGNER, M. ARAGAKI, R. BAKER, M.L. DAUGHTREY, R.H. LAWSON, J.D. MACDONALD, J.F. TAMMEN \& G.L. WORF -1988 - Current and future research directions of ornamental pathology. Plant Disease 72: 926-934.

DICK, M.W. -1990-Keys to Pythium. University of Reading Press, $64 \mathrm{pp}$.

GARRET, S.D. -1970- Unspecialised parasites. In: Pathogenic Root-Infecting Fungi. London, Cambridge University Press, $31 \mathrm{pp}$.

HENDRIX, F.F. \& W. CAMPBELL -1973 Pythiums as plant pathogens. Annual Review of Phytopathology 11: 77-98.

KAGEYAMA, K. \& E. B. Nelson -2003 Differential inactivation of seed exudate 
stimulation of Pythium ultimum sporangium germination by Enterobacter cloacae influences biological control efficacy on different plant species. Applied and Environnemental Microbiology Feb: 1114-1120.

MIDDLETON, J. T. -1943 - The taxonomy, host range, and geographical distribution of the genus Pythium. Memoirs of the Torrey Botanical Club 20: 1-171.

ONEP (Office National De L'eau Potable). -1996Les algues dans les retenues de barrages utilisées pour la production d'eau potable. Royaume Du Maroc, Edition ONEP.

ONEP (Office National De L'eau Potable).-1998Alimentation en eau potable. Actions environnementales pour la protection des ressources. Royaume Du Maroc, Edition ONEP.

PAUL, B. -1982- Champignons aquatiques du Sahara Algérien: Pythium Pringsheim. Cryptogamie-Mycologie 3 : 57-62.

PAUL, B. -1986a- Anew species of Pythium from Algerian waters. Hydrobiologia 131: 31-38.

PAUL, B. -1986b- An aquatic species, Pythium toruloides sp. Nov., from Algeria. Transactions of the British Mycological Society 86: 330-334.

PAUL, B. -1986c- A new non zoosporic species of Pythium from Algeria. Hydrobiologia 140: 233-236.
PAUL, B. -1994a- Some species of Pythium isolated from soil and water samples collected in Western Africa. Microbiological Research 149: 217-222.

PAUL, B. -1994b- Some species of Pythium isolated from cultivated soils in Northern France. Cryptogamie Mycologie 15 (4): 263 271.

PAUL, B. -2002- ITS region of Pythium canariense sp.nov., its morphology and its interaction with Botrytis cinerea. FEMS Microbiology Letters 208: 135-141.

PLAATS-NITERINK, A.J. Van der. -1981Monograph of the genus Pythium. Baarn, Centraalbureau voor Schimmelcultures, Studies in Mycology 21: 1-242.

RAYNAL, G. -1980- Evaluation en conditions artificielles de la résistance des plantules de Luzerne aux Pythium. Possibilités de lutte chimique. Annals of Phytopathology 12 (2):119-130.

WALKER R., A.A. POWELL \& B. SEDDON 1998- Bacillus isolates from the spermosphere of peas and dwarf French beans with antifungal activity against Botrytis cinerea and Pythium species. Journal of Applied Microbiology 84: 791-801.

WATERHOUSE, G.A. -1967- Keys to Pythium Pringsheim. Mycological P. CMI 109: 1-15. 